\title{
The Success Rate of Two Explant Types of Stevia (Stevia rebaudiana Bertoni) in Various Sterilant Formulas
}

\author{
Riedha Kariena ${ }^{1}$, Nofia Hardarani' ${ }^{1}$ Hilda Susanti ${ }^{2 *}$ \\ ${ }^{1}$ Agroecotechnology Department, Faculty of Agriculture, Universitas Lambung Mangkurat \\ ${ }^{2}$ Agronomy Department, Faculty of Agriculture, Universitas Lambung Mangkurat \\ Jl. Jend. A. Yani KM 36, Banjar Baru, Kalimantan Selatan, 70714, Indonesia \\ *Corresponding author: hildasusanti@ulm.ac.id
}

\section{ARTICLE HISTORY \\ Received : 11 August 2020 \\ Revised : 21 September 2020 \\ Accepted : 28 September 2020}

\section{KEYWORDS}

Stevia;

In-vitro;

Contamination;

Tissue Culture;

\begin{abstract}
This study aims to determine the effect of interaction between several sterilants and types of explants and determine the best interaction with stevia culture's success rate. This study was designed using a Factorial Complete Randomized Design with two factors and three replications. The first factor is sterilant formulas i.e: fungicide $3 \%+$ alcohol $70 \%+$ Bayclin $5 \%$; fungicide $3 \%+$ bactericide $6 \%+70 \%$ alcohol + Bayclin $5 \%$; sublimate $0.1 \%+70 \%$ alcohol + Bayclin $5 \%$; and fungicide $3 \%+$ bactericide $6 \%+$ sublimate $0.1 \%+$ alcohol $70 \%+$ Bayclin $5 \%$. The second factor is explant types, i.e., stevia nodes and leaves. The variables observed are the percentage of contamination (\%), percentage of alive explants (\%), and browning percentage. The interaction between sterilants and explant types only had a significant effect on the percentage of alive explants. The best interactions of sterilant formulas and explant types on the percentage of alive explants are $0.1 \%$ sublimate $+70 \%$ alcohol $+5 \%$ Bayclin and leaf explants.
\end{abstract}

\section{INTRODUCTION}

Stevia (Stevia rebaudiana Bertoni) is a unique herb that secretes high potency sweetener called stevioside in its leaves (Heryanto, 2014). This natural sweetener contains non-calories, and its sweetness is 300 times sweeter compared to the sucrose contains in sugar obtained from sugarcane (Djajadi, 2015). Stevia has offered several advantages such as its use is safe for diabetic people due to it does not affect the blood sugar level, has a low glycemic index and zero calories which contributed to lower chance of having tooth decay, improves digestion, and it is good for weight management (Raini \& Isnawati, 2011).

Stevia plants' cultivation is important because this plant can be used as a sugar substitute to meet the need for sugar consumption, and it is also safer for human health. Generally, this plant is cultured using its stems. However, the propagation using stems has produced a small number of stevia plants. This production scarcity is an obstacle to providing superior seeds on a large scale. Its low seed viability and lightweight also have caused this plant seeds to be impossible to be used as material for future planting (Djajadi, 2015).

The tissue culture technique is an ideal technique to propagate the desired plants in a larger number in a shorter time with great characteristics, resistant to pest and disease (Sinta, 2016). One effort affecting the success of plant propagation is sterilization. Contamination often occurs in the in-vitro technique. In the research of Hadiyana, et al. (2015), they confirmed that stevia propagation through tissue culture technique enabled the plants to be easily contaminated, resulted in the death of explants even though all tools and explants used in this research have been sterilized.

This study aimed to determine the interaction between several sterilants and explant types to the success of stevia culture and find the best interaction between them.

\section{MATERIALS AND METHODS}

\subsection{Variables Observed}

This research was held in Tissue Culture Laboratory, Department of Agronomy, Faculty of Agriculture, Universitas Mulawarman, from July to August 2018. The materials used in this research were stevia explants, MS media, fungicide, bactericide, alcohol $70 \%$, cloth bleach Bayclin, sublimate, Tween 20, Polyvynyl Pyrolidone (PVP), and distilled water. The tools used were beaker glass, measuring cylinder, analytical balance, graduated pipette, aluminum foil paper, clingwrap, Laminar Air Flow, culture rack, and lamps. 
The research used Factorial Completely Randomized Design (CRD) with two factors: 4 different sterilants and types of explants. Those sterilants (s) were $\mathrm{s} 1$ (fungicide $3 \%+$ alcohol $70 \%+$ Bayclin 5\%), s2 (fungicide $3 \%+$ bactericide $6 \%+$ alcohol $70 \%+$ Bayclin 5\%), s3 (sublimate 1\% + alcohol 70\% + Bayclin 5\%), s4 (fungicide $3 \%+$ bactericide $6 \%+$ sublimate $0.1 \%+$ alcohol $70 \%+$ Bayclin 5\%). There were 2 types of explants (e), such as nodes $\left(\mathrm{e}_{1}\right)$ and leaves $\left(\mathrm{e}_{2}\right)$. There were 8 treatment combination which replicated 3 times, so it had 24 experimental unit. Each experimental unit consist of 6 culture jars, resulted in 144 experimental units in total.

\subsection{Variables Observed}

Variables observed in this research were the percentage of contamination (\%), percentage of alive explants (\%), and percentage of browning (\%). Data were recorded daily for 30 days.

\subsection{Statistical Data Analysis}

A level test with a probability 5\% was performed to analyze the homogeneity of data collected. If the data were homogenous, the analysis was continued using ANOVA, where Tukey's HSD test at a probability level 5\% was employed when there were significant differences. These data were also statistically analyzed using software Minitab 18.

\section{RESULTS AND DISCUSSIONS}

\subsection{Percentage of Contamination}

The results showed that the application of sterilants influenced the percentage of contamination on explants. The application of fungicide 3\% + alcohol 70\% + Bayclin 5\% has possessed the highest percentage of contamination on both explants, nodes, and leaves. This has been proven by the appearance of bacteria and fungi in the explant media. It might happen due to this application was the simpler mixture compared to other experiments. The sterilants made from fungicide $3 \%+$ alcohol $70 \%+$ Bayclin 5\% have considered ineffective reducing the number of contaminants on explants.

Table 1. Percentage of contamination caused by disinfecting various

\begin{tabular}{|c|c|}
\hline Sterilant & $\begin{array}{c}\text { Percent of } \\
\text { contamination } \\
(\%)\end{array}$ \\
\hline Fungicide 3\% + alcohol 70\% + Bayclin 5\% & $88.89 \mathrm{a}$ \\
\hline $\begin{array}{l}\text { Fungicide } 3 \%+\text { bactericide } 6 \%+\text { alcohol } \\
70 \%+\text { Bayclin } 5 \%\end{array}$ & $80.56 \mathrm{ab}$ \\
\hline sublimate $0.1 \%+$ alcohol $70 \%+$ Bayclin & $38.89 \mathrm{c}$ \\
\hline $\begin{array}{l}\text { fungicide } 3 \%+\text { bactericide } 6 \%+\text { sublimate } \\
0.1 \%+\text { alcohol } 70 \%+\text { Bayclin } 5 \%\end{array}$ & $52.78 \mathrm{bc}$ \\
\hline
\end{tabular}

The lowest percentage of contamination was exhibited by applying sublimate $0.1 \%+$ alcohol $70 \%+$ Bayclin $5 \%$. The sublimate played an important role in reducing contamination. This formula of sterilant has been the best application to reduce contamination on both node and leaf explants. The research of Fauzan, et al. (2017) on teak bud explants found that the tiny hairs that appeared on the surface of leaf explants have enabled sublimate to optimally suppressed the contamination due to its high phenolic compound. A high concentration of sublimate added in the sterilant has produced a high aseptic culture, resulted in a decrease of contamination percentage caused by fungi and bacteria.

The application of complex formula of sterilant (fungicide $3 \%+$ bactericide $6 \%+$ sublimate $0.1 \%+$ alcohol $70 \%+$ Bayclin 5\%) on explant media showed insignificant result of contamination compared to application of sublimate $0.1 \%+$ alcohol $70 \%+$ Bayclin 5\%. Daud, et al. (2012) has confirmed that the application of sublimate $0.1 \%$ in $15-30$ seconds has enabled the leaf and stem explants of Agar Wood (Aquilaria malaccensis) to be aseptic $83-90 \%$.

The highest contamination caused by bacteria and fungi reached up to $58 \%$ and $42 \%$. Genus Rhizoporus, Mucor, Aspergillus, and Saccharomyces were found in this research. Oratmangun, et al. (2017) investigated that Rhizopus has dark colonies with colored and bright mycelium. Mucor has white colonies with bright mycelium. Aspergillus has colonies with dark white-brown color, and Saccharomyces is transparent, smooth, and moist. The bacteria found in this research came from the Genus Agrobacterium, Lactobacillus, and Streptococcus. Putri (2009) evaluated that those three genus have moist colonies with different colors. Agrobacterium is pink in color, Lactobacillus is yellow, and Streptococcus is white.

\subsection{Percentage of Alive Explants}

Table 2 described that there was high interaction between the application of sublimate $0.1 \%+$ alcohol $70 \%+$ bayclin $5 \%$ and leaf explants (83.33\%). However, this high percentage was not significant compared to leaf explants applied with fungicide $3 \%+$ bactericide $6 \%+$ sublimate $0.1 \%,+$ alcohol $70 \%+$ bayclin $5 \%$. 
Table 2. Interaction between sterilant and explant type to the percentage of alive explants

\begin{tabular}{|l|c|c|}
\hline \multicolumn{1}{|c|}{ Sterilant } & \multicolumn{2}{c|}{ Types of explants } \\
\cline { 2 - 3 } & Node & Leaf \\
\hline Fungicide 3\% + Alcohol 70\% + Bayclin 5\% $\left(\mathrm{s}_{1}\right)$ & $5.56 \mathrm{~b}$ & $5.56 \mathrm{~b}$ \\
\hline Fungicide 3\%+ Bactericide 6\%+ Alcohol 70\%+ Bayclin 5\% $\left(\mathrm{s}_{2}\right)$ & $5.56 \mathrm{~b}$ & $16.67 \mathrm{~b}$ \\
\hline Sublimate $0.1 \%+$ Alcohol 70\%+ Bayclin 5\% $\left(\mathrm{s}_{3}\right)$ & $22.22 \mathrm{~b}$ & $83.33 \mathrm{a}$ \\
\hline Fungicide 3\% + Bactericide 6\% + Sublimate 0.1\%+ alcohol 70\%+ Bayclin 5\% $\left(\mathrm{s}_{4}\right)$ & $11.11 \mathrm{~b}$ & $50.00 \mathrm{ab}$ \\
\hline
\end{tabular}

Means followed by the same letters in the same columns did not differ significantly, as determined by Tukey's HSD test at $\alpha=5 \%$.

The leaf explants showed the highest percentage of alive and fresh explants. At one week after the application, the explant still had green leaves. The leaves experienced the upward curling with its tip still beneath the media at two weeks after application. Surprisingly, the explants applied with fungicide $3 \%+$ bactericide $6 \%+$ sublimate $0.1 \%+$ alcohol $70 \%+$ Bayclin 5\% experienced browning on its leaves and has no responsibility towards the sterilant. The application of sublimate $0.1 \%+$ alcohol $70 \%$ + Bayclin $5 \%$ on leaf explants has triggered explants to have the highest alive explants.

Morphologically, stevia explants, which are hairy, are the main cause of a higher percentage of alive leaf explants. The leaf has a thinner trichome compared to the trichome possessed by the node. Leaf trichomes in the stevia plant only can be found in the lower part of the leaf, while the node trichome can be found spread on the surface of the stem. This has caused sterilant was difficult to penetrate the surface of explants.

\subsection{Percentage of Browning}

The percentage of browning was influenced by the application of sterilants and types of explants. The application of fungicide 3\% + bactericide $6 \%+$ alcohol $70 \%$ + Bayclin $5 \%$ and the application of sublimate $0.1 \%+$ alcohol $70 \%+$ Bayclin 5\% have caused browning reached up to $17 \%$ to both node and leaf explants. Browning happened and can be visually seen when explants did get browned, followed by the media. Browning in leaf explants occurred 18 days after planting and 21 days after planting in node explants.
Browning can occur due to the normal activity of polyphenol oxidation (PPO) in vivo; generally, it occurred at senescence or deteriorated cells (Hutami, 2016). In tissue culture, browning is caused by increased oxidative enzymes and their polymerase (Tabiyeh, et al., 2006). Gunawan (2007) stated that based on its reaction, browning could be divided into two, enzymatic and non-enzymatic brownings. Enzymatic browning initiated by the enzyme PPO, which in the presence of oxygen catalyzes the oxidation of o-diphenols to o-quinones. The polymerization of o-quinones produces brown pigments. Non-enzymatic browning is a process of browning without the activity of enzymes. In this research, there were 3 culture jars with different treatments found to have browning explants, 2 node explants applied with fungicide $3 \%+$ bactericide $6 \%+$ alcohol 70\% + Bayclin 5\% and applied with sublimate $0.1 \%$ + alcohol $70 \%+$ Bayclin 5\%. In the leaf explants, browning occurred in explants applied with fungicide $3 \%$ + bactericide $6 \%+$ alcohol $70 \%+$ Bayclin $5 \%$.

We have evaluated that the percentage of browning in this research was considered low (17\%). It is due to the addition of PVP $0.02 \mathrm{~g} / \mathrm{L}$. PVP was added to the media. PVP helped to reduce the browning explants. Admojo \& Indrianto (2016) have done the research about browning reduction on rubber leaf, and they found that soaking rubber leaf explants into sterile ascorbate acid $100 \mathrm{mg} / \mathrm{L}$ for 30 minutes before planting and incubated them in a dark room would initiate low browning (7.5\%) with fewer browning explants (30\%). Batt \& Dhar (2004) also added that micropropagation of Myrica esculenta (box myrtle) by adding PVP $0.5 \%$ effectively eliminated phenolic compound, resulted in optimal growth of the explants.

Table 3. Percentage of browning on explants applied with different sterilants

\begin{tabular}{|c|c|c|}
\hline \multirow{3}{*}{ Sterilant } & \multicolumn{2}{|c|}{ Explant type } \\
\hline & Node $\left(\mathrm{e}_{1}\right)$ & Leaf $\left(\mathrm{e}_{2}\right)$ \\
\hline & \multicolumn{2}{|c|}{....................\%................. } \\
\hline Fungicide 3\% + Alcohol 70\% + Bayclin 5\% ( $\left.\mathrm{s}_{1}\right)$ & 0.00 & 0.00 \\
\hline Fungicide 3\% + Bactericide 6\% + Alcohol 70\% + Bayclin 5\% (s2) & 17.00 & 17.00 \\
\hline Sublimate $0.1 \%+$ Alcohol $70 \%+$ Bayclin $5 \%\left(\mathrm{~s}_{3}\right)$ & 17.00 & 0.00 \\
\hline Fungicide $3 \%+$ Bactericide $6 \%+$ Sublimate $0.1 \%+$ Alcohol $70 \%+$ Bayclin $5 \%\left(\mathrm{~s}_{4}\right)$ & 0.00 & 0.00 \\
\hline
\end{tabular}

Hutami (2016) stated that the phenolic compound experienced high oxidation when the plant cell cut or experienced senescent, causing plant tissue (explants) to be brown and failed to grow. Stevia has a woody and hairy stem, while it has thin hair on the leaves' surface. Browning occurred in stevia explant in this research 
triggered by high oxidation of phenolic compound. Therefore, the addition of PVP or antioxidant is needed in the media or sterilants used in the research to develop the explants better.

\section{CONCLUSIONS}

1. The interaction between sterilants and types of explants only had a significant effect on the percentage of alive explants.

2. The application of sublimate $0.1 \%+$ alcohol $70 \%+$ bayclin $5 \%$ and leaf explant were the best interaction we found in this research.

\section{REFERENCES}

Admojo, L., \& Indrianto, A. (2016). Pencegahan browning fase inisasi kalus pada kultur midrib daun klon karet (Hevea brasiliensis Muell Arg) Pb 330. Indonesian Journal of Natural Rubber Research, 34(1), 25-34.

Bhatt, I. D., \& Dhar, U. (2004). Factors controlling micropropagation of Myrica esculenta buch.-Ham. ex D. Don: a high value wild edible of Kumaun Himalaya. African Journal of Biotechnology, 3(10), 534-540.

Daud, N. H., Jayaraman, S., \& Mohamed, R. (2012). Methods Paper: An improved surface sterilization technique for introducing leaf, nodal and seed explants of Aquilaria malaccensis from field sources into tissue culture. Aspac J. Mol Biol Biotechnol, 20, 55-58.

Djajadi, D. (2015). Pengembangan tanaman pemanis Stevia rebaudiana (Bertoni) di Indonesia. Perspektif, 13(1), 25-33.

Fauzan, Y. S. A., \& Tajuddin, T. (2017). Efektivitas Merkuri Klorida $\left(\mathrm{HgCl}_{2}\right)$ Pada Sterilisasi Tunas Samping Jati (Tectona grandis) In Vitro. Jurnal Bioteknologi \& Biosains Indonesia (JBBI), 4(2), 78-84.

Gunawan, I. (2007). Perlakuan sterilisasi eksplan anggrek kuping gajah (Bulbophyllum beccarii Rchb. f) dalam kultur in vitro. Skripsi. Departemen Konservasi Sumberdaya Hutan dan Ekowisata Fakultas Kehutanan IPB. Bogor.

Hadiyana, A., \& Syabana, M. A. (2015). Iniasi tunas secara kultur jaringan pada Stevia (Stevia rebaudiana Bertoni) dengan kosentrasi indole butyric acid (IBA) dan benzyl amino purine (BAP) yang berbeda. Jurnal Agroekoteknologi, 7(2).

Heryanto, A. F., Soegihardjo, C. J., \& Purwijantiningsih, L. E. (2014). Optimalisasi Produksi Steviosida dari Kalus Daun Stevia rebaudiana
Bertoni dengan Variasi Kombinasi Zat Pengatur Tumbuh Optimization of Stevioside Production from Callus Derived from Stevia rebaudiana Bertoni Leaves with Variation of Plant Growth Regulators Combination.

Hutami, S. (2016). Ulasan masalah pencoklatan pada kultur jaringan. Jurnal Agrobiogen. 4(2) : 83-88.

Oratmangun, K. M., Pandiangan, D., \& Kandou, F. E. (2017). Deskripsi Jenis-Jenis Kontaminan Dari Kultur Kalus Catharanthus roseus (L.) G. Donnaman. Jurnal MIPA, 6(1), 47-52.

Putri, A. I. (2009). Kajian Glycocalyx bakteri Pada Kontaminasi Ulin (Eusideroxylon zwageri) In-Vitro. Jurnal Pemuliaan Tanaman Hutan, 3(1), 33-42.

Raini, M., \& Isnawati, A. (2011). Kajian: khasiat dan keamanan stevia sebagai pemanis pengganti gula. Media Penelitian dan Pengembangan Kesehatan, 21(4).

Sinta, M. M. (2019). Pertumbuhan, Produksi Biomassa, dan Kandungan Glikosida Steviol pada Lima Klon Stevia Introduksi di Bogor, Indonesia. Jurnal Agronomi Indonesia (Indonesian Journal of Agronomy), 47(1), 105-110.

Tabiyeh, D. T., Bernard, F., \& Shacker, H. (2005, May). Investigation of glutathione, salicylic acid and GA3 effects on browning in Pistacia vera shoot tips culture. In IV International Symposium on Pistachios and Almonds 726 (pp. 201-204). 